\title{
The moratorium on loan repayments during the Covid-19 Pandemic in Europe: a comparative analysis of loan moratoria in selected European countries
}

PhD. student Jan SKRABKA ${ }^{1}$

\begin{abstract}
This paper examines the moratorium on loan repayments, which was intended to relieve debtors in a difficult situation during the COVID-19 pandemic. In this study, various aspects of such moratoria are critically discussed and compared from an international perspective. Some debtors were significantly hit hard by the pandemic, whereas others were no. But should the moratoria apply to all of them? The free-rider problem, or even harm to some clients, are among the unintended results of the moratorium. Moreover, the loan repayment moratorium has different effects on the traditional banking sector and on P2P lending platforms. Such differences were not discussed sufficiently before adopting the moratoria. The different effects might have a negative impact on some debtors, on some creditors, or on the market and society in general. Along with using some traditional legal research methods, this paper takes a comparative perspective on loan repayment moratoria in different EU countries among. The conclusions of the paper may help regulators and lawmakers prepare more balanced regulations of loan repayments in the next crisis. Future regulations should reflect the perspectives of both debtors and creditors.
\end{abstract}

Keywords: Loan repayment, loan repayment moratorium, moratorium, banking, P2P lending, banking law, COVID-19.

JEL Classification: E44, G21, G28, K22, K23

DOI: $10.24818 / \mathrm{TBJ} / 2021 / 11 / \mathrm{SP} / 02$

\section{Introduction ${ }^{2}$}

The current COVID-19 pandemic has been perhaps the most important topic for all countries for more than a year. The virus spread easily around the world due to the global nature of contemporary society, especially the ever-increasing mobility of people, goods, and transactions. Different states have chosen different strategies to tackle the virus; nevertheless, there have been substantial impacts on society, various sectors of the national economy, and financial markets. ${ }^{3}$ Among the

\footnotetext{
${ }^{1}$ Jan Skrabka - PhD. student at the Faculty of International Relations, Prague University of Economics and Business, Czech Republic, jan.skrabka@vse.cz.

${ }^{2}$ The article has been supported by the grant No. F2/60/2021 „Recent Changes in Business, Financial and IT law in the Czech Republic in Response to the Covid-19 Pandemic" of the Prague University of Economics and Business.

${ }^{3}$ Susskind D, Vines D. The economics of the COVID-19 pandemic: An assessment. Oxford Review of Economic Policy. 2020. vol 36. p. S1-S13. Available from: https://academic.oup.com/oxrep/article /36/Supplement_1/S1/5899022.
} 
strategies, various states have tried to limit the adverse impacts of COVID-19 by amending certain legislation or by creating new laws and regulations. ${ }^{4}$

The article focuses on loan repayment moratoria, the policy's usage during the COVID-19 pandemic, and its intended outcomes. But this paper also discusses problematic aspects of the moratoria, which impact various stakeholders and the society as a whole. This unique legal policy has been used in different countries with various modifications; some of them were more restrictive than others. In order to analyze the problematic aspects of the moratoria, a comparative legal approach is used in this article. Whereas previous papers have focused on one country at a time, ${ }^{5}$ the problems in designing loan moratoria are more clearly visible when different types of moratoria in different countries are compared, as this paper shows.

The article explains that the moratoria were adopted at the very beginning of the COVID-19 pandemic in Europe, when the economic situations of debtors were usually better than during the long-term pandemic which followed. Moreover, at least some of the problematic aspects of the moratoria could have been resolved during a longer planning and drafting phase before the moratoria were implemented.

\section{Overview of loan repayment moratoria in selected European countries}

This article aims to highlight not only the intended aims of moratoria, but also the negative effects such policies have had. It provides an overview of the basic parameters of loan repayment moratoria in selected European Union countries. Such international comparisons help to highlight the different approaches countries took, and to uncover the possible problematic design of the moratoria in some countries. Of the 27 European Union countries, seven countries were selected for this study. The countries were selected by their different approaches towards loan repayment moratoria, therefore this article allows the international comparison of different approaches. The seven countries are sorted in alphabetic order in Table 1.

\footnotetext{
${ }^{4}$ Alderman, R., et al. Consumer Law and Policy Relating to Change of Circumstances due to the COVID-19 pandemic. Journal of Consumer Policy, vol. 43, no. 3, 2020, pp. 437-450. doi:10.1007/s10603-020-09463-z; Martínez, I. J. R. 2020. Moratorium in the payment of mortgages during the state of alarm by COVID-19. Actualidad Juridica Iberoamericana no. 12bis. pp. 492-501.

${ }^{5}$ Augsburg B, Malde B. Is borrowing relief ending too soon? post-lockdown income recovery and loan moratoriums in rural India. Economic and Political Weekly. 2021;56(2):13-15. Available from: https://www.epw.in/journal/2021/2/commentary/borrowing-relief-ending-too-soon.html.
} 
Table 1. Overview of loan repayment moratoria in the seven selected EU countries

\begin{tabular}{|c|c|c|c|c|c|}
\hline Countries & $\begin{array}{l}\text { Loan moratorium } \\
\text { imposed by the } \\
\text { legistation/regulator }\end{array}$ & $\begin{array}{l}\text { Opt-in or opt-out } \\
\text { method for debtors }\end{array}$ & $\begin{array}{l}\text { Applicable for } \\
\text { repayments due and } \\
\text { payable between } \\
\text { \{period of } \\
\text { moratorium) }\end{array}$ & $\begin{array}{l}\text { Extension by } \\
\text { (deferred } \\
\text { repayments) }\end{array}$ & $\begin{array}{l}\text { Consumer loans or } \\
\text { corporate loans }\end{array}$ \\
\hline Austria & Yes & Opt-in & $\begin{array}{l}1 \text { April } 2020 \text { and } 31 \\
\text { Jantary } 2021\end{array}$ & By 10 months & $\begin{array}{l}\text { Loans for consumers } \\
\text { and micro enterprises }\end{array}$ \\
\hline Gech Republic & Yes & Opt-in & $\begin{array}{l}1 \text { May } 2020 \text { and } 31 \\
\text { October } 2020\end{array}$ & By 3 or 6 months & $\begin{array}{l}\text { Both for consumer } \\
\text { and corporate loans }\end{array}$ \\
\hline Germamy & Yes & Opt-out & $\begin{array}{l}1 \text { April and } 30 \text { June } \\
2020\end{array}$ & 3 months & Consumer loans only \\
\hline Hungary & Yes & Opt-out & $\begin{array}{l}19 \text { March } 2020 \text { and } \\
31 \text { June } 2021\end{array}$ & $\begin{array}{l}\text { by the period equal to } \\
\text { the moratorium }\end{array}$ & $\begin{array}{l}\text { Both for consumer } \\
\text { and corporate loans }\end{array}$ \\
\hline Poland & $\begin{array}{l}\text { No, only private general } \\
\text { loan moratorium by the } \\
\text { Polish Banking } \\
\text { Association }\end{array}$ & N/A & N/A & N/A & N/A \\
\hline Romania & Yes & Opt-in & $\begin{array}{l}30 \text { March } 2020 \text { and } \\
31 \text { March } 2020\end{array}$ & By up to 9 months & $\begin{array}{l}\text { Both for consumer } \\
\text { and corporate loans }\end{array}$ \\
\hline Sweden & $\begin{array}{l}\text { No general public or } \\
\text { private moratorium }\end{array}$ & N/A & N/A & N/A & N/A \\
\hline
\end{tabular}

Table prepared by the author based on the following sources: https://www.esrb.europa.eu /home/search/co ronavirus/html/index.en.html

The majority of EU countries have implemented some type of loan moratoria, but some countries did not, such as Poland, Norway, or Sweden. ${ }^{6}$ The comparison in Table 1 shows great variability in the most important aspects of loan moratoria in different countries. Some of the analyzed countries have implemented much longer moratoria than others. Similarly, the moratorium applies only to consumer loans in Germany, to consumer loans and micro-entities ${ }^{7}$ in Austria, and to both consumer and corporate loans in the Czech Republic and Romania.

There are also European Banking Authority (EBA) guidelines on loan moratoria, but the EBA is not entitled to issue any binding regulations for setting up loan repayment moratoria in the EU Member States. The purpose of EBA guidelines is to clarify the application of the definitions of default and forbearance ${ }^{8}$ in the

\footnotetext{
${ }^{6}$ Drabancz A, Grosz G, Palicz A, Varga B. Experiences with the Introduction of a Payment Moratorium in Hungary. Financial and Economic Review. Vol. 20 Issue 1, March 2021. pp. 5-42. http://doi.org/10.33893/FER.20.1.542. Available from https://en-hitelinteze tiszemle.mnb.hu/ letoltes/fer-20-1-st1-drabancz-grosz-palicz-varga.pdf.

${ }^{7}$ Commission Recommendation of 6 May 2003 concerning the definition of micro, small and mediumsized enterprises (notified under document number C(2003) 1422) (OJ L 124, 20.5.2003, pp. 36-41).

${ }^{8}$ The loans which benefit from the general moratorium (both in case of public and private moratorium) are not classified automatically as forborne if the following criteria are met: ,, The moratorium was launched in response to the COVID-19 pandemic. The moratorium has to be broadly applied. The moratorium has to apply to a broad range of obligors. The same moratorium offers the same conditions. The moratorium changes only the schedule of payments. The moratorium does not apply to new loans granted after the launch of the moratorium. "EBA. Guidelines on legislative and non-legislative moratoria on loan repayments applied in the light of the COVID-19 crisis as of 2 April, 2020. EBA/GL/2020/02. Available from: https://www.eba.europa.eu/sites/default/documents/files/document _library/Publications/ Guidelines/2020/.
} 
context of loan repayment moratoria, which were adopted in some EU Member States. The EBA guidelines were adopted after the EBA made a statement on 25 March 2020, in which different aspects of moratoria were discussed. However, the EBA guidelines could have been prepared earlier, at the beginning of March 2020, to allow the Member States to consider taking a more harmonized approach. ${ }^{9}$ On the other hand, it is questionable whether the EBA as a regulatory body should set any rules in advance.

\section{Do loan repayment moratoria help or harm borrowers?}

Despite the sound reasons for implementing loan repayment moratoria in various countries around Europe (and the world), the legislation was prepared during a stressful and dramatic pandemic in 2020 and 2021. The tense situation did not allow for a gradual preparation and years-long political discussion of various legislative proposals aimed at helping the economy. Because of the market and political pressure, the legislators were forced to act quickly. ${ }^{10}$ Therefore, a closer (ex-post) analysis would help us better understand the overall impact moratoria have on the market and society.

\subsection{The intended aims of loan repayment moratoria}

The specifics differ for loan moratoria in different European countries; nevertheless, the reasons for the moratoria are more economic than legal.

\subsubsection{Vulnerability of debtors during the pandemic}

Retrospectively, several reasons can be identified for why some European governments decided to take unprecedented actions related to the loans and mortgages sector. Due to the big negative shock ${ }^{11}$ that COVID-19 caused to the financial and labour markets, the governments and regulators were anticipating a massively increased number of unpaid debts from loans drawn. The crisis caused by the pandemic revealed that many households are vulnerable to measures taken against COVID-19, which have restricted some jobs, or closed certain types of businesses. Considering the already high debt burden of some households or small

\footnotetext{
${ }^{9}$ One of the tasks of EBA is to promote a harmonized approach and take ,,a leading role in promoting transparency, simplicity and fairness in the market for consumer financial products or services across the internal market". https://www.eba.europa.eu/about-us/missions-and-tasks.

${ }^{10}$ The detailed problems of policymaking during the COVID-19 pandemic are discussed, for example, by Bergen et al. The authors discuss the decision-making process; they specifically elaborate on the decision methods under uncertainty. Berger L, Berger N, Bosetti V, Gilboa I, Hansen LP, Jarvis C, Marinacci M, Smith RD. Rational policymaking during a pandemic. Proceedings of the National Academy of Sciences the United States of America. 2021 Jan 26;118(4):e2012704118. doi: 10.1073/pnas.2012704118. Available from: https://www.pnas.org/content/pnas/118/4/e2012704118 .full.pdf.

${ }^{11}$ Teresienè, D., G. Keliuotytè-staniulènienè, and R. Kanapickienè. Sustainable Economic Growth Support through Credit Transmission Channel and Financial Stability: In the Context of the covid19 Pandemic. Sustainability (Switzerland). 2021. 13 (5). pp. 1-37. doi:10.3390/su13052692. Available from: https://www.mdpi.com/2071-1050/13/5/2692.
} 
businesses, such a situation posed a major threat for them. ${ }^{12}$ Certain sectors, such as tourism and hospitality, have been devastated, and those major changes influence the whole society. ${ }^{13}$ The experience from the USA shows that the loan moratoria are valuable as they help to significantly reduce defaults by providing households with some time for refinancing. ${ }^{14}$

\subsubsection{Faster recovery after the pandemic}

Based on the analysis of non-performing loans during and after the crisis (including the financial crisis in 2008), it is clear that non-performing loans are a critical factor of the post-crisis economic recovery. ${ }^{15}$ The adverse effects that the COVID-19 crisis would have on bank loans were not predicted only by the most affected countries, but also on the international level by the Bank for International Settlements already in April 2020. ${ }^{16}$ However, the immediate but short-term benefits that loan repayment moratoria have for the market can be overshadowed by the long-term negative results of these macroeconomic policies, which can postpone non-performing loans without really providing a permanent solution to the problem. ${ }^{17}$ According to the World Bank data from December 2020, the nonperforming loans ratio remains unchanged in Europe as a result of the moratoria policies; nevertheless, the borrowers' distress is expected to rise. ${ }^{18}$

\subsection{Problematic aspects of the design of loan repayment moratoria}

Despite the motivation for the adoption of loan moratoria that was mentioned above, unintended consequences and problematic aspects of this

${ }^{12}$ Buehler, K., Conjeaud, O., Giudici, V., Samandari, H., Serino, L., Vettori, M., Webanck, L., White, O., (2020). Leadership in the time of coronavirus: COVID-19 response and implications for banks, McKinsey\&Company, Available from: https:/www.mckinsey. com/industries/financialservices/our-insights/leadership-in-the-time-of-coronavirus-covid-19-response-and-implicationsfor-banks.

13 Al-Fadly, A. Impact of Covid-19 on Smes and Employment. Entrepreneurship and Sustainability 2020 Issues 8 (2). pp.629-648. doi:10.9770/jesi.2020.8.2(38). Available from: https://jssidoi.org/ jesi/article/720.

${ }^{14}$ Golding, E., L. S. Goodman, R. Green, and S. Wachter. The Mortgage Market as a Stimulus Channel in the COVID-19 Crisis. Housing Policy Debate. 2021. 31 (1): 66-80. doi:10.1080/10511482.2020.1850015. Available from: https://www.tandfonline.com/doi/ abs/10.1080/10511482.2020.1850015?journalCode $=$ rhpd20.

${ }^{15}$ Ari A, Chen S, and Ratnovski L. COVID-19 and Non-Performing Loans: Lessons from past Crises (27 May, 2020). Available at SSRN: https://ssrn.com/abstract=3632272 or http://dx.doi.org/10.2139 /ssrn.3632272

${ }^{16}$ Basel Committee on Banking Supervision, Measures to reflect the impact of Covid-19, April 2020, available at https://www.bis.org/ bcbs/publ/d498.pdf. ISBN 978-92-9259-358-2

${ }^{17}$ Miglionico, A. The Great Lockdown: The UK Regulatory Responses to the Pandemic Crisis. Law and Economics Yearly Review, vol. 9, 2020, pp. 94-111. available at http://www.laweconomicsyearlyreview.org.uk/Law_and_Economics_Yearly_Review_LEYR_ Journal_vol_9_part_1_2020.pdf.

18 World Bank. COVID-19 and Non-Performing Loan Resolution in the Europe and Central Asia region: Lessons learned from the global financial crisis for the pandemic. 2020. Available from: https://pubdocs.worldbank.org/en/460131608647127680/FinSAC-COVID-19-and-NPL-PolicyNote-Dec2020.pdf. 
legislation can be found. Some of them should have been raised ex-ante before the adoption of the moratoria; certain problematic aspects can only be discovered and analyzed ex-post or in a comparative view.

\subsubsection{Loan repayment moratoria as mandatory or voluntary for borrowers?}

Making a policy mandatory or voluntary raises many questions. The first question is whether to set a mandatory loan repayment moratorium by law, the government, or a financial regulator. Next, should the private loan moratorium be introduced by respective national banking associations, as happened in Poland? Alternatively, should this question be left open for individual banks to decide, without any compulsory legal provisions, so that each bank can apply its own rules, case by case? The clearly predictable solution is for individual states to prepare policies. But the countries could have created a more harmonized approach with international cooperation or faster reaction by the EBA.

On the other hand, transferring the power to banks to grant or reject a deferred payment of loans could result in unpredictable actions, or in a too strict approach by banks. However, the author believes that such significant state interventions in existing relationships between creditors and debtors should only be an ultimate solution when it is obvious that the market cannot handle the extreme situation caused by voluntary loan moratoria. The reason for this opinion lies primarily in the other problematic aspects of mandatory loan moratoria, such as inflexibility and difficulties in designing the appropriate scope, and in the state's ability to implement the legislation that effectively targets the problem.

\subsubsection{Opt-in and opt-out principles of loan repayment moratoria}

There is a second problematic aspect arising from the international comparison in table 1 . This is the question of applying the opt-in or opt-out principle for loan moratoria. ${ }^{19}$ Although the opt-out method is easy to use and less complex for banks, the author considers the opt-in method to be more appropriate for different clients during this pandemic situation. The author finds no legal or moral arguments to allow a debtor who is not in economic difficulties, or who even increases his turnover or profit during a crisis, to get relief for loans. The opt-out principle results in less targeted relief, and it increases the likelihood that the free-rider problem will occur. $^{20}$

Similar to any other form of special help, a loan moratorium should be accessible only for those debtors in need. Finally, the overview prepared by the Czech Republic's regulator shows that only $14 \%$ of holders of both consumer and

\footnotetext{
${ }^{19}$ The opt-in and opt-out principles in the legal regulation are discussed by Almlöf, H., Bjuggren, P. A regulation and transaction cost perspective on the design of corporate law. European Journal of Law and Economics. 2019. 47(3), p. 407-433. doi:10.1007/s10657-019-09620-x. Available from: https:/link.springer.com/article/10.1007/s10657-019-09620-x.

${ }^{20}$ Merickova B, Muthová N. The Value of Public Good. Free Rider Problem. Proceedings of the 21st international conference Current Trends in Public Sector Research. 2017. p. 66-73. Available from: $\mathrm{https} / / / \mathrm{www}$. researchgate.net/publication/334163385_The_Value_of_Public_Good_Free_Rider_ Problem.
} 
corporate loans in the Czech Republic used the opt-in procedure to get extensions on repayments. ${ }^{21}$ This low number might indicate that not all clients are in economic difficulty; therefore, they do not all necessarily need a loan moratorium.

\subsubsection{Scope of application - should corporate loans be included as well?}

The third major problem in a loan moratorium is the loan category in which the loan repayments moratorium applies. Some countries included only consumer loans to the policy (e.g., Germany), whereas some others included both consumer and corporate loans (e.g., the Czech Republic and Romania). Meanwhile, the moratorium in Austria is applicable to all consumer loans, and also to some corporate loans.

However, Austria used a unique threshold for the moratorium with companies, as only micro-entities are eligible for relief. Having different rules for micro-entities, for other types of SMEs, and for larger companies is subject to criticism in Austria. Such arbitrary decisions may even violate the constitutional principle of equality. ${ }^{22}$ The author believes that businesses are the backbone of every economy; however, they are also employers. Therefore, they should have the same rights as households in terms of getting access to loan moratoria.

\subsubsection{Incorrect timing of some moratoria}

The timing of measures is another crucial aspect. It has a direct impact on the success of such measures. As can be seen in Table 1, loan moratoria were usually adopted in the selected countries at the beginning of the pandemic, in March or April 2020., The moratoria assessed here retrospectively were thus adopted at the very beginning of a long pandemic crisis, but some countries extended the period of moratoria. In general, however, these special measures have not lasted during the whole crisis. ${ }^{23}$

In the opinion of the author, some moratoria were adopted earlier than necessary, as the overall (long-term) economic situation of debtors was not very much influenced by the COVID-19 pandemic in March or April 2020. Not only were moratoria adopted earlier than usually necessary, but they also ended rather earlier

${ }^{21}$ Česká národní banka. Statistika odkladu splátek a úvěrů v programech COVID. 2020. Available from: https://www.cnb.cz/ export/sites/cnb/cs/dohled-financni-trh/.galleries/souhrnne_informace fin_trhy/statistika_odkladu_splatek_a_uveru_v_programech covid/zprava_o_moratoriich_2020.pdf.

${ }^{22}$ Schmalzl, S. Legislative moratoria on loan repayments - are certain SMEs more equal than others? 2020. Available from: https://www.internationallawoffice.com/Newsletters/Banking-FinancialServices/Austria/Schima-Mayer-Starlinger/Legislative-mora toria-on-loan-repayments-are-certainSMEs-more-equal-than-others.

${ }^{23}$ With the exception of Hungary, which extended the moratorium. 
in the majority of the selected countries. ${ }^{24}$ However, the economic situation of some debtors, especially of those who lost their jobs, or who are directly affected by the closure of their businesses, has not yet improved. ${ }^{25}$ Such debtors might get a false sense of safety by using the moratorium early, but due to their worsening economic situation, they may become unable to repay their debts if the moratorium ends too early. It therefore seems to be more appropriate to offer moratoria not from the very beginning of a pandemic, but in the next stages of the pandemic, during times of deepening economic problems for households and companies. Finally, quickly drafted legislation and rapid adoption of moratoria may lead to future problems.

\subsubsection{Different consequences for banks, for Fintech, and for P2P platforms}

The loan repayment moratoria adopted in European countries apply to banks but also to other creditors, such as Fintech and P2P platforms that provide loans. However, the strict banking regulation ${ }^{26}$ of banks and their mandatory stress tests give the banks an advantage over Fintech and P2P platforms, which are less heavily regulated, and do not have an obligation to undergo stress tests. ${ }^{27}$ Therefore, the banks have higher capital buffers and reserves compared to Fintech/P2P platforms, which are not bound by stringent regulations and capital requirements.

Moreover, the reason for protecting debtors (and especially those who are consumers) by using loan moratoria is weakened in the case of $\mathrm{P} 2 \mathrm{P}$ platforms, where consumers can also act as creditors (investors). The mandatory loan moratoria problem substantially differs in P2P platforms compared to banks. Debtors who delay repaying loans administered by $\mathrm{P} 2 \mathrm{P}$ platforms may cause liquidity problems which can harm creditors. Especially Creditors who are consumers do not usually have the expertise they need to assess the risks fully.

In order to discuss the best practices for relief measures, the European Commission held two roundtables with numerous associations of companies from the financial sector and with European regulators. After the two roundtables, a

${ }^{24}$ The same problem of inappropriate timing of the moratorium has also been experienced in some other countries around the world. Augsburg B, Malde B. Is borrowing relief ending too soon? Postlockdown income recovery and loan moratoriums in rural India. Economic and Political Weekly. 2021;56(2):13-15.

${ }^{25}$ Fratantoni, M. Forbearance during the Pandemic: What do we Know thus Far? Journal of Structured Finance. 202026 (3). pp. 19-27. doi:10.3905/JSF.2020.1.110. Available from: https://jsf.pmresearch.com/content/26/3/19.

${ }^{26}$ de Andres, P., L. Arranz-Aperte, and J. A. Rodriguez-Sanz. "Fit and Proper" Regulations in the Banking Industry: What we have Learnt in the Post-Crisis Years. Journal of Governance and Regulation, vol. 9, no. 3, 2020, pp. 84-95. doi:10.22495/jgrv9i3art6. Available from: https://virtusinterpress.org/Fit-and-proper-regulations-in-the-banking-industry-What-we-havelearnt-in-the.html.

27 The effects of stress testing on banks and adoption of new stress testing COVID-19 exercises in the US, UK and Eurozone area. See Henry, J. Banking System Stress Testing and COVID-19: A First Summary Appraisal. Journal of Risk Management in Financial Institutions, vol. 14, no. 1, 2021, pp. 7-24. 
summary of the best practices for banks and non-banking creditors was prepared. ${ }^{28}$ Both the banks and non-banks creditors are encouraged to be particularly flexible, especially towards the most vulnerable debtors. On the other hand, debtors are encouraged to start making their repayments as soon as practically possible, or to seek debt counselling instead of accumulating their obligations.

\section{Conclusion}

A loan repayment moratorium is an extraordinary legal instrument. It has been used in various countries, both in Europe and around the world, during the COVID-19 pandemic. It has been used to provide relief for debtors during a difficult economic situation. The approaches different European countries took towards loan moratoria were not harmonized. Therefore, each country has adopted different rules. In order to compare the different aspects of the loan repayment moratoria, a comparison was made between seven EU countries with different approaches towards loan repayment moratoria.

The results of the analysis show that there are public and private moratoria, and that some are general while others are specific. However, some EU countries have not adopted any loan moratoria. There are opt-in and opt-out relief policies, but the opt-out system may result in a higher number of free-riders. Some countries have a moratorium only for consumers, whereas other countries allow companies to participate as well. The author believes that the inclusive approach (for consumers and companies) is more appropriate as it also supports companies as employers. Therefore, it increases the overall stability of the labour market.

Finally, selecting the right time for a loan repayment moratorium seems crucial because when the adoption is too early, it does not allow authorities to have enough time to identify possible problems in the proposed legislation. For this reason, the author believes that moratoria should not be implemented at the very beginning of the pandemic, but rather later during the crisis, when households and companies can be expected to get into economic trouble.

\section{Bibliography}

1. Al-Fadly, A. Impact of Covid-19 on Smes and Employment. Entrepreneurship and Sustainability 2020 Issues 8 (2). pp.629-648. doi:10.9770/jesi.2020.8.2(38). Available from: https://jssidoi.org/jesi/article/720.

2. Alderman, R., et al. Consumer Law and Policy Relating to Change of Circumstances due to the COVID-19 pandemic. Journal of Consumer Policy, vol. 43, no. 3, 2020, pp. 437-450. doi:10.1007/s10603-020-09463-z.

3. Ari A, Chen S, and Ratnovski L. COVID-19 and Non-Performing Loans: Lessons from past Crises (27 May, 2020). Available at SSRN: https://ssrn.com/abstract $=3632272$ or http://dx.doi.org/10.2139/ssrn.3632272.

28 European Commission. Best Practices in relation to relief measures offered to consumers and businesses in the context of the COVID-19 crisis. 14 July, 2020. Available from: https://eapb.eu/index.php?option=com_attachments\&task=download\&id=2032:best-practices_en. 
4. Augsburg B, Malde B. Is borrowing relief ending too soon? post-lockdown income recovery and loan moratoriums in rural India. Economic and Political Weekly. 2021; 56(2):13-15. Available from: https://www.epw.in/journal/2021/2/commentary/ borrowing-relief-ending-too-soon.html.

5. Basel Committee on Banking Supervision, 'Measures to reflect the impact of Covid19', April 2020, available at https://www.bis.org/bcbs/publ/d498.pdf. ISBN 978-929259-358-2.

6. Berger L, Berger N, Bosetti V, Gilboa I, Hansen LP, Jarvis C, Marinacci M, Smith RD. Rational policymaking during a pandemic. Proceedings of the National Academy of Sciences the United States of America. 2021 Jan 26;118(4):e2012704118. doi: 10.1073/pnas.2012704118. Available from: https://www.pnas.org/content/pnas/ 118/4/e2012704118.full.pdf.

7. Buehler, K., Conjeaud, O., Giudici, V., Samandari, H., Serino, L., Vettori, M., Webanck, L., White, O., (2020). Leadership in the time of coronavirus: COVID-19 response and implications for banks, McKinsey\&Company, Available from: https://www.mckinsey.com/industries/financial-services/our-insights/leadership-inthe-time-of-coronavirus-covid-19-response-and-implications-for-banks.

8. Česká národní banka. Statistika odkladu splátek a úvěrů v programech COVID. 2020. Available from: https:/www.cnb.cz/export/sites/cnb/cs/dohled-financni-trh/.galleries /souhrnne_informace_fin_trhy/statistika odkladu_splatek_a_uveru_v_programech_covid/zprava_o_moratoriich_2020.pdf.

9. Commission Recommendation of 6 May 2003 concerning the definition of micro, small and medium-sized enterprises (notified under document number C(2003) 1422) (OJ L 124, 20.5.2003, pp. 36-41).

10. de Andres, P., L. Arranz-Aperte, and J. A. Rodriguez-Sanz. "Fit and Proper" Regulations in the Banking Industry: What we have Learnt in the Post-Crisis Years. Journal of Governance and Regulation, vol. 9, no. 3, 2020, pp. 84-95. doi:10.22495/jgrv9i3art6. Available from: https://virtusinterpress.org/Fit-and-properregulations-in-the-banking-industry-What-we-have-learnt-in-the.html.

11. Drabancz A, Grosz G, Palicz A, Varga B. Experiences with the Introduction of a Payment Moratorium in Hungary. Financial and Economic Review, Vol. 20 Issue 1, March 2021, 5-42. http://doi.org/10.33893/FER.20.1.542. Available from https://enhitelintezetiszemle.mnb.hu/letoltes/fer-20-1-st1-drabancz-grosz-palicz-varga.pdf.

12. EBA. Guidelines on legislative and non-legislative moratoria on loan repayments applied in the light of the COVID-19 crisis as of 2 April, 2020. EBA/GL/2020/02. Available from: https://www.eba.europa.eu/sites/ default/documents/files/document library/Publications/Guidelines/2020/.

13. European Commission. Best Practices in relation to relief measures offered to consumers and businesses in the context of the COVID-19 crisis. 14 July, 2020. Available from: https://eapb.eu/index.php?option $=$ com_ attachments\&task= download\&id=2032:best-practices_en.

14. Fratantoni, M. Forbearance during the Pandemic: What do we Know thus Far? Journal of Structured Finance. 202026 (3). pp. 19-27. doi:10.3905/JSF.2020.1.110. Available from: https://jsf.pm-research.com/ content/26/3/19.

15. Golding, E., L. S. Goodman, R. Green, and S. Wachter. The Mortgage Market as a Stimulus Channel in the COVID-19 Crisis. Housing Policy Debate. 2021. 31 (1): 66-80. doi:10.1080/10511482.2020.1850015. Available from: https://www.tandfonline. com/doi/abs/10.1080/10511482.2020.1850015?journalCode $=$ rhpd20. 
16. Henry, J. Banking System Stress Testing and COVID-19: A First Summary Appraisal. Journal of Risk Management in Financial Institutions, vol. 14, no. 1, 2021, pp. 7-24.

17. Martínez, I. J. R. 2020. Moratorium in the payment of mortgages during the state of alarm by COVID-19. Actualidad Juridica Iberoamericana no. 12bis. pp. 492-501

18. Merickova B, Muthová N. The Value of Public Good. Free Rider Problem. Proceedings of the 21st international conference Current Trends in Public Sector Research. 2017. pp. 66-73. Available from: https://www.research gate.net/publication/ 334163385_The_Value_of_Public_Good_Free_Rider_Problem.

19. Miglionico, A. The Great Lockdown: The UK Regulatory Responses to the Pandemic Crisis. Law and Economics Yearly Review, vol. 9, 2020, pp. 94-111. available at http://www.laweconomicsyearlyreview.org.uk/

Law_and_Economics_Yearly_Review_LEYR_Journal_vol_9_part_1_2020.pdf.

20. Schmalzl, S. Legislative moratoria on loan repayments - are certain SMEs more equal than others? 2020. Available from: https://www.internationallawoffice.com /Newsletters/Banking-Financial-Services/Austria/Schi ma-MayerStarlinger/Legislative-moratoria-on-loan-repayments-are-certain-SMEs-more-equalthan-others.

21. Susskind D, Vines D. The economics of the COVID-19 pandemic: An assessment. Oxford Review of Economic Policy. 2020. vol 36. p. S1-S13. Available from: https://academic.oup.com/oxrep/article/36/Supplement_1/S1/5899022.

22. Teresienè, D., G. Keliuotytè-staniulènienè, and R. Kanapickienè. Sustainable Economic Growth Support through Credit Transmission Channel and Financial Stability: In the Context of the covid-19 Pandemic. Sustainability (Switzerland). 2021. 13 (5). pp. 1-37. doi:10.3390/su13052692. Available from: https://www.mdpi.com/2071-1050/ $13 / 5 / 2692$.

23. Almlöf, H., Bjuggren, P. A regulation and transaction cost perspective on the design of corporate law. European Journal of Law and Economics. 2019. 47(3), pp. 407-433. doi:10.1007/s10657-019-09620-x. Available from: https://link.springer.com/article/ 10.1007/s10657-019-09620-x.

24. World Bank. COVID-19 and Non-Performing Loan Resolution in the Europe and Central Asia region: Lessons learned from the global financial crisis for the pandemic. 2020. Available from: https://pubdocs.worldbank.org/ en/460131608647127680/ FinSAC-COVID-19-and-NPL-Policy-Note-Dec2020.pdf. 